\title{
Development of a Yorùbá Arithmetic Multimedia Learning System
}

\author{
Safiriyu Eludiora ", Habeeb Oluwo \\ Department of Computer Science \& Engineering, Obafemi Awolowo University, Nigeria
}

Copyright $(2017$ by authors, all rights reserved. Authors agree that this article remains permanently open access under the terms of the Creative Commons Attribution License 4.0 International License

\begin{abstract}
In recent times, the endangerment of Yorùbá has highly been speculated among Yorùbá intellectuals, indigenes and enthusiasts alike. In an effort to promote the learning and use of Yorùbá numeral system in carrying out day-to-day activities and transactions, the development of a Yorùbá arithmetic learning system will help bridge the gap between lost Yorùbá traditions of the transaction and modern day business activities. The design of this project was conceptualized using Unified modelling language (UML) tools. The resulting design and software specification was implemented using Python programming language due to its cross-platform compatibility and PyQt graphical user interface (GUI) module for the GUI. System evaluation was done using questionnaire to determine how the system is perceived by potential users. It was observed that $90 \%$ were unable to evaluate the addition expressions; $55 \%$ were unable to evaluate subtraction expressions, $65 \%$ were unable to evaluate multiplication expressions and $90 \%$ were unable to evaluate division expressions. It can be concluded from both research and the system developed that in order to make the Yorùbá language more relevant in the world today, attempts such as this project must be encouraged. The issue of the almost non-existent use of Yorùbá numeral must be addressed by producing learning systems or aids to help the teaching and learning of the Yorùbá numerals.
\end{abstract}

Keywords Yorùbá, Numeral, Arithmetic, Endangerment, Culture, Traditional, System

\section{Introduction}

According to "Reference [1]", language is defined as "fundamentally the means by which men communicate with each other and with themselves". It is through the e of language that man can express thoughts, exchange ideas and give words to emotions. The Yorùbá language is one of the three prominent indigenous languages (Hausa, Igbo, and Yorùbá) spoken in Nigeria. Apart from Nigeria with about
30 million Yorùbá speakers, Yorùbá is spoken in part of Togo, Republic of Benín, Ghana, Sudan, Sierra-Leone and Côte D'Ivoire. Outside Africa, a great number of speakers of the language are in Brazil, Cuba, Trinidad and Tobago [2].

In recent times, the endangerment of Yorùbá has highly been speculated among Yorùbá intellectuals, indigenes and enthusiasts alike. "Reference [3]" considers a language dead or endangered if "they are no longer spoken in the form in which we find them in ancient writings".

The Yorùbá Counting/Numbering system is the aspect of the language that is at most susceptible to falling out of use. Recent Yorùbá speaking generation and indigenes increasingly find it difficult to use Yorùbá numbers in enumerating objects or making transactions with local speakers. A case of this is when a child attempts to buy a commodity from a typical Yorùbá speaker (can understand and speak Yorùbá only) trader in the market, the child will find it difficult in bargaining the price of such commodity when the trader cannot understand the -English word and numbers the child is saying and the child cannot understand the Yorùbá numbers the trader is saying is her price.

In an effort to promote the learning and use of Yorùbá numeral system in carrying out day-to-day activities and transactions, the development of a Yorùbá arithmetic learning system will help bridge the gap between lost Yorùbá traditions of transactions and modern day business activities. It can also serve the purpose of promoting the learning of the Yorùbá numbering system among students in schools.

Low use of the Yorùbá counting system is a problem as it denotes the gradual extinction of the Yorùbá language. Many Yorùbá adults, youths, and children do not know how to count and calculate using Yorùbá numbers. As a result of this, this project aims to develop a software that will enable Yorùbá speakers and learners learn and perform counting and calculations using the Yorùbá arithmetic learning system was developed.

The system is capable of making an addition, subtraction, multiplication and division arithmetic operations strictly integer (non-decimal) numbers within the range of 0 to 1000 . Thus, arithmetic computation cannot be made on negative 
numbers and fractional numbers as they have no representation in the Yorùbá numeral system. The sound for the system was recorded for numbers 0 to 100 .

Section I introduces the study, section II discusses the literature review. System design is described in section III. Section IV addresses software implementation and section V discusses evaluation and discussion.

\section{Literature Review}

In this section different studies were reviewed to determine the strength of this study and add to the body of the knowledge of literature.

\section{A. Yorùbá Counting Techniques}

According to "Reference [8]", there are conventional terms used to denote 'less than' and 'greater than' in the Yorùbá counting system. For instance, in the cardinal context, 'ó dín.../din ní...' (It reduces/reduces by) is used to count from 15 'mẹẹ̀dógún' (i.e mú-árùn-dí-ní-ogún meaning twenty lesser than five) to 19 'mọ́kàndínlógún' (i.e mú-ọkan-din-ní-ogún meaning twenty lesser than one). "Reference [12]" further states that ogún is the basic word for twenty, okòo the word used when counting objects. According to "Reference [12]", each of the decades is coded; units in 1-4 are derived by adding to the decade, while units in 5-9 are formed by subtracting from the next decade. The odd decades are derived by subtracting ten from the next even decade i.e. 'lé ní...' (increase by...) is used from 1- 4 (i.e. adding to 10) while 'ó din ní...' (decrease by...) is from 5 - 9 (i.e. subtracting from 10).

It is also noticed that the influence of tens is not in the number twenty. According to "Reference [8]", the counting pattern, from what is observed from numbers 11 to 14 , changes from numbers 21 to 24. "Reference [8]" proceeds that numbers 21 to 24 are counted as mọkànlélógún (i.e. mú-ọkan-lé-ní-ogún meaning take one more over twenty), méjìlélógún (i.e. múèjì-lé-ní-ogún meaning take two more over twenty), mẹtàlélógún (i.e. mú-ẹta-lé-ní-ogún meaning take three more over twenty) and mẹrinlélogún (i.e. mú-èrin-lé-ní-ogún meaning take four more over twenty) respectively. Using "Reference [8]"'s conclusion from the previous paragraph, the counting of numbers from 25 is '...dín lọgbọ̀n' (...less than thirty) which denotes that 25 is 'márùn-ún-dín-ní-ọgbọ̀n/mẹẹ̀dọgbọ̀n' meaning (five lesser than thirty) up to 29 'mọ́kàndínlọggbọn' meaning (one lesser than thirty). 30 is ogbọ̀n. The same procedure is applied in the counting from 31 to 50 .

"Reference [8]" further states that though 'oggbọn' has no semantic connection with either twenty or forty, and the semantic import of some previous numbers will be noticed and more importantly, the significance of arithmetic concepts such as division, multiplication, subtraction, addition. "Reference [8]" continues the analysis of the
Yorùbá counting system semantics from ogọowàá/ogún mẹ́wàa $(20$ x 10) which is 200 , conventionally called 'igba'. The author states that from 200 'igba' above, 20 is no longer expressed as ogún e.g.

220 'okòó-lé-ní-igba/okòóléerúgba' (twenty more than 200).

Numbers from 500 follow a new pattern that replaces 10 and 20 with 100 and 200 respectively as computation bases begin. From 500 of the pattern of counting changes by adding the prefix 'ẹẹdẹ-' to any number that is less by 100 . This shows that centuries larger than 200 is derived by either subtracting 100 form the next bicentenary or by multiplying 200 by the appropriate unit e.g.

$$
\begin{aligned}
& 500 \text { (ẹẹedẹ́-ẹgbẹta) }=600(200 * 3) \text { [ẹgbẹta/ igba mẹta] - } \\
& 100 \text { (ogọruun-ún) } \\
& 700 \text { (ẹeẹéé-ẹbẹ̀rin) }=800(200 * 4) \text { [ẹgbẹrin/igba mẹrin] } \\
& -100 \text { (ọgọrùn-ún) }
\end{aligned}
$$

\section{B. Yorùbá Arithmetic System}

"Reference [13]" the use of Yorùbá in the teaching and learning of mathematics in Nigerian schools, reiterated the basic operations in mathematics as the four cardinal arithmetic operations which are addition $(+)$, subtraction $(-)$, division $(\div)$ and multiplication $(\mathrm{x})$. The Authors proceeded to itemize these arithmetic operations in Yorùbá language. The following are the arithmetic operations as they can appear in Yorùbá language:

- $\quad+$ : Àmì àròpọ̀

- $\quad$ - : Àmì àyọkúrò

- $\quad \mathrm{x}$ : Àmì ìsọdipúpò

- $\quad \div$ or $/$ : Àmì pínpín

'Àmì àròpọ̀' is a sign denoting the addition of two or more numbers together whose result will always be greater in value than its individual input variables except in the case of zero being an operand. 'Àmì àyọúrò' is the opposite of the addition operation as this is clearly a reduction process (Subtraction). 'Àmì ìsọdipúpọ̀' is multiple increment of the multiplier which is always greater than addition once the multiplier is not 1. 'Àmì pínpín' is the opposite of multiplication which involves the division of a number, the dividend by another number, the divisor.

\section{Yorùbá Language and its Numbering system in Nigerian Education}

The role of Yorùbá language in education in Nigeria has reduced drastically over the years. This has contributed to alienation of the young and elite from the Yorùbá language. "Reference [14]" discovered that "parents have little or no influence on the language acquisition of their children. The wards, school mates and the playmates of children generally influence the language of the child much more than that of the parents". It can be inferred from this that unless parents 
make concerted efforts to plant in their children the zeal to learn about culture and tradition, they would most likely acquire the speech pattern of their play group.

"Reference [2]" surmised that "another reason for the present Yorùbá speakers' preference for the English's decimal system over the vigesimal system of Yorùbá is that the decimal system does not ask the comprehension skill of the hearers much unlike the vigesimal system, which requires a series of cognitive processes. Even nearly all electronic and print media have adopted the English decimal system at the detriment of Yorùbá vigesimal numeral system".

"Reference [15]" also identified the Yorùbá numeral system as the first major setback in efforts to use Yorùbá language in communication in science and technology. "Reference [15]" submits that the contributing factor to the growth of any language comes from introducing scientific terms into the language and advises that we make modifications to our language to such an extent that scientists can use it in research and this can therefore result in "meaningful and timely expansions to the language".

\section{Interactive Language Learning Software}

In recent times, there have been increasing interests in the use computers for language teaching and learning. Not more than a decade ago, the use of computers in the language classroom was of concern only to a small number of specialists [16]. However, with the advent of the Internet and multimedia computing, the role of computers in language instruction has now become an important issue confronting large numbers of language teachers and researchers throughout the world [17].

Speaking on the evolution of CALL (Computer Aided Language Learning), "Reference [18]" notes that during the five decades of CALL development, materials have gone from an emphasis on basic textual gap-filling tasks and simple programming exercises to interactive multimedia presentations with sound, animation and full-motion video.

Classroom learning is also enhanced through the use of visuals. On the use of visuals in teaching, "Reference [19]" concludes that visuals promote a student's ability to organize and process information.

Visuals can also be utilized to challenge students to think on levels that require higher order thinking skills [20].

Finally, technology provides opportunities for teachers to meet the needs of students with various learning styles through the use of multiple media [21].

\section{System Design}

Essentially three key things are discussed in the section. The software, database and audio system designs.

\section{A. Software Design}

Figure 1 shows the activity diagram of the system. There are two for gaining access to the system; select module and access general module. The Select module has four modules. From each module, the user can perform the four arithmetic operations. Alternatively, the user can use access general module to perform the four arithmetic tasks. Figure 3 and 4 show the sequence diagram of the two access points. Figure 2 is the class diagram of the whole system.

\section{B. Audio System Design}

The audio system will enable the speech output capability of the application and will demonstrate how each number sounds and is uttered. Each number in the Yorùbá numeral system will be recorded into an audio file. The application is limited to perform computations not greater than 1000 (ẹgbèrún) but due to memory considerations, the numbers will be recorded from 0 (oódo) to 100 (ogoọrún).

The system will include a module 'Sound' that will play the audio file corresponding to each number inputted for computation.

\section{(1) Audio File Format}

The audio file format that will be used for this system is the WAV audio format. Standard Windows digital audio. The WAV format was developed by Microsoft for use on Intel-based computers. Professional PC-based digital audio recording and editing systems use WAV files as their standard, and it is expanding into the Mac world.

\section{(2) Number - Audio Mapping}

The relationship between the system's set of Yorùbá numerals and the system's set of audio files is one-to-one i.e. there is exactly one audio sound to one Yorùbá numeral. The association between a Yorùbá numeral and its audio file will be made by specifying the audio file's name as the Arabic equivalent of that Yorùbá numeral. Thus the createSoundFile(num) method in the Speech() class will get and load the audio file whose name corresponds with the one specified as the method's argument. The play() method is responsible for playing the loaded audio file thereby stimulating speech output. 


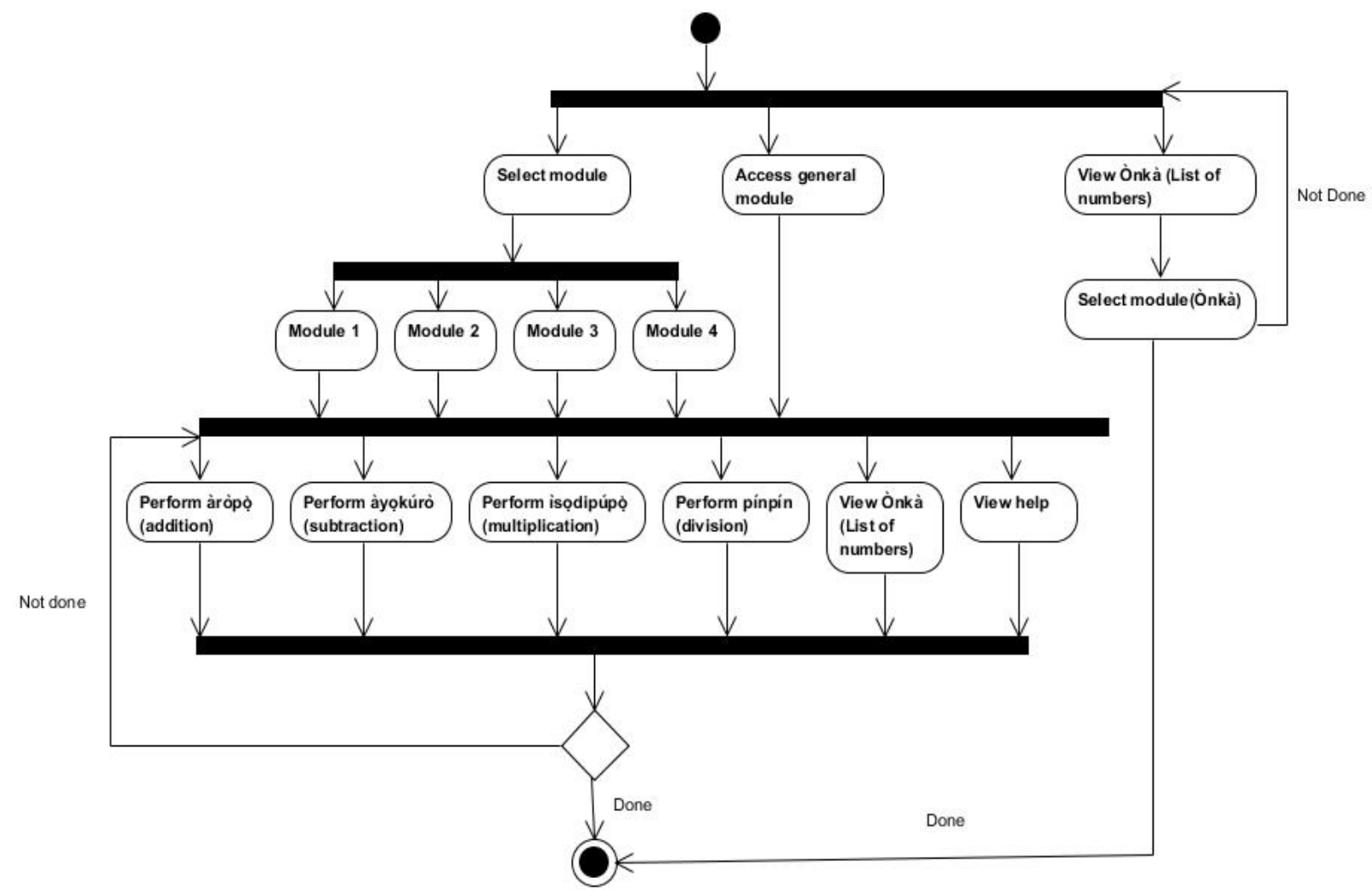

Figure 1. Activity Diagram of the System

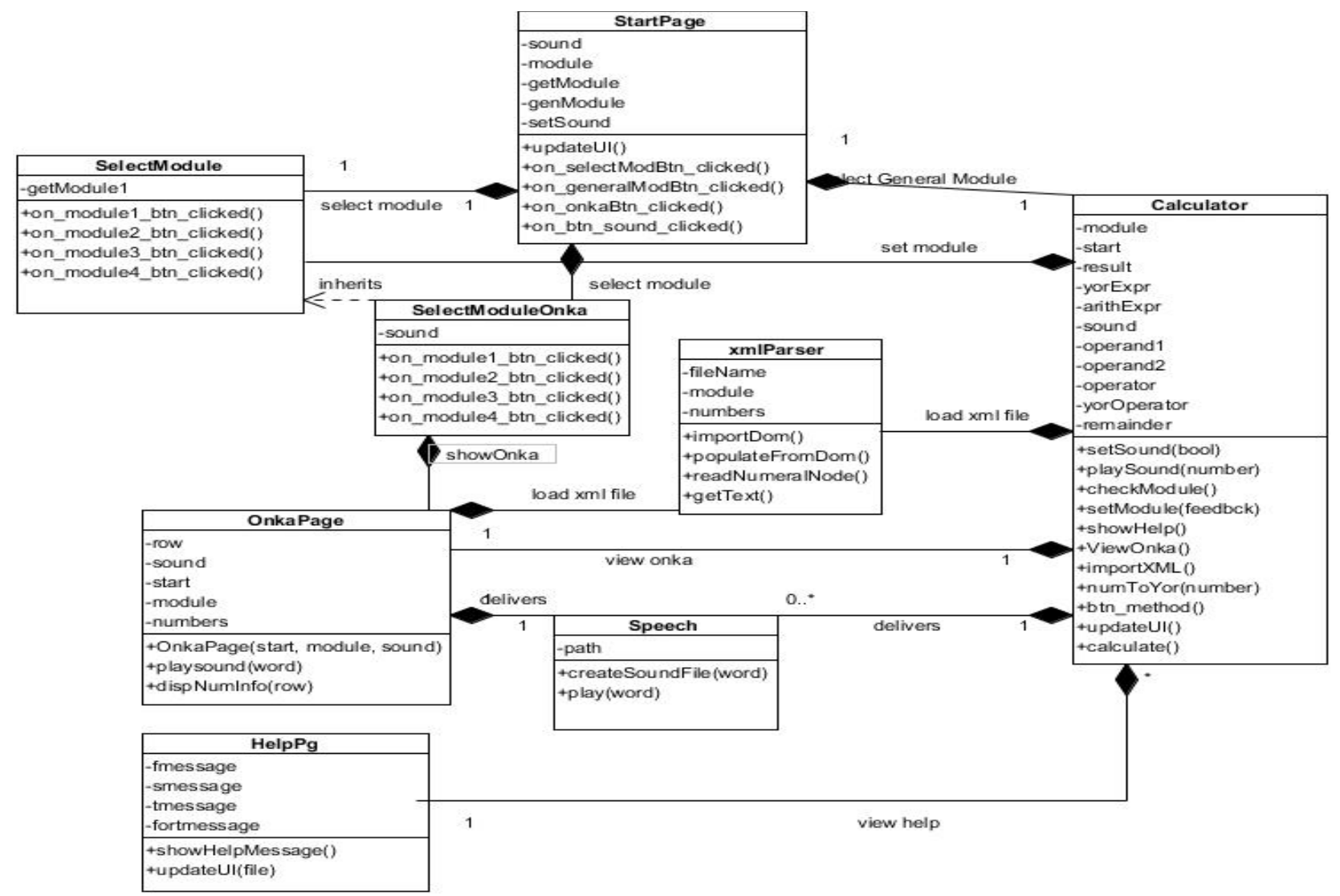

Figure 2. Class Diagram of the System 


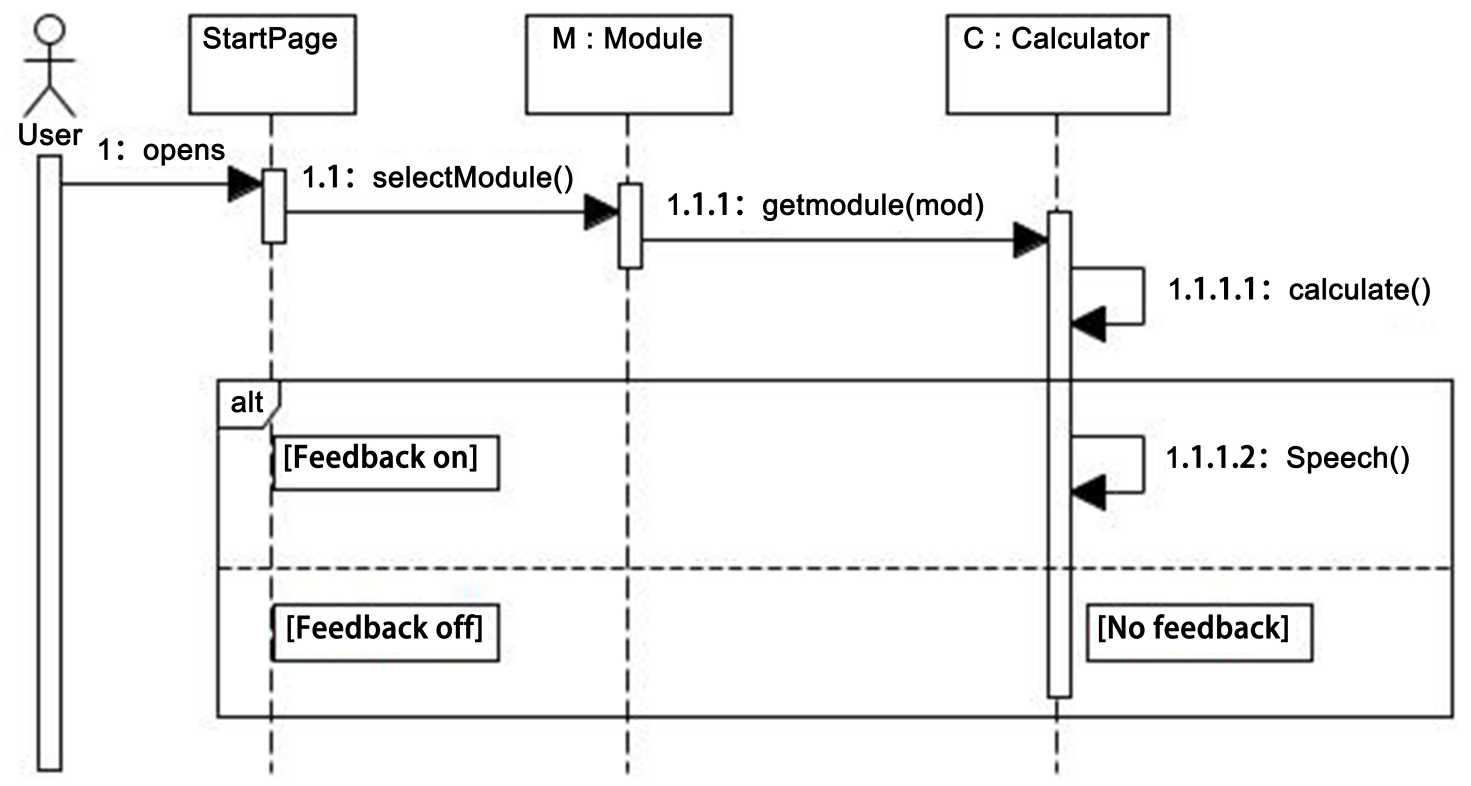

Figure 3. Sequence diagram for "select module" activity

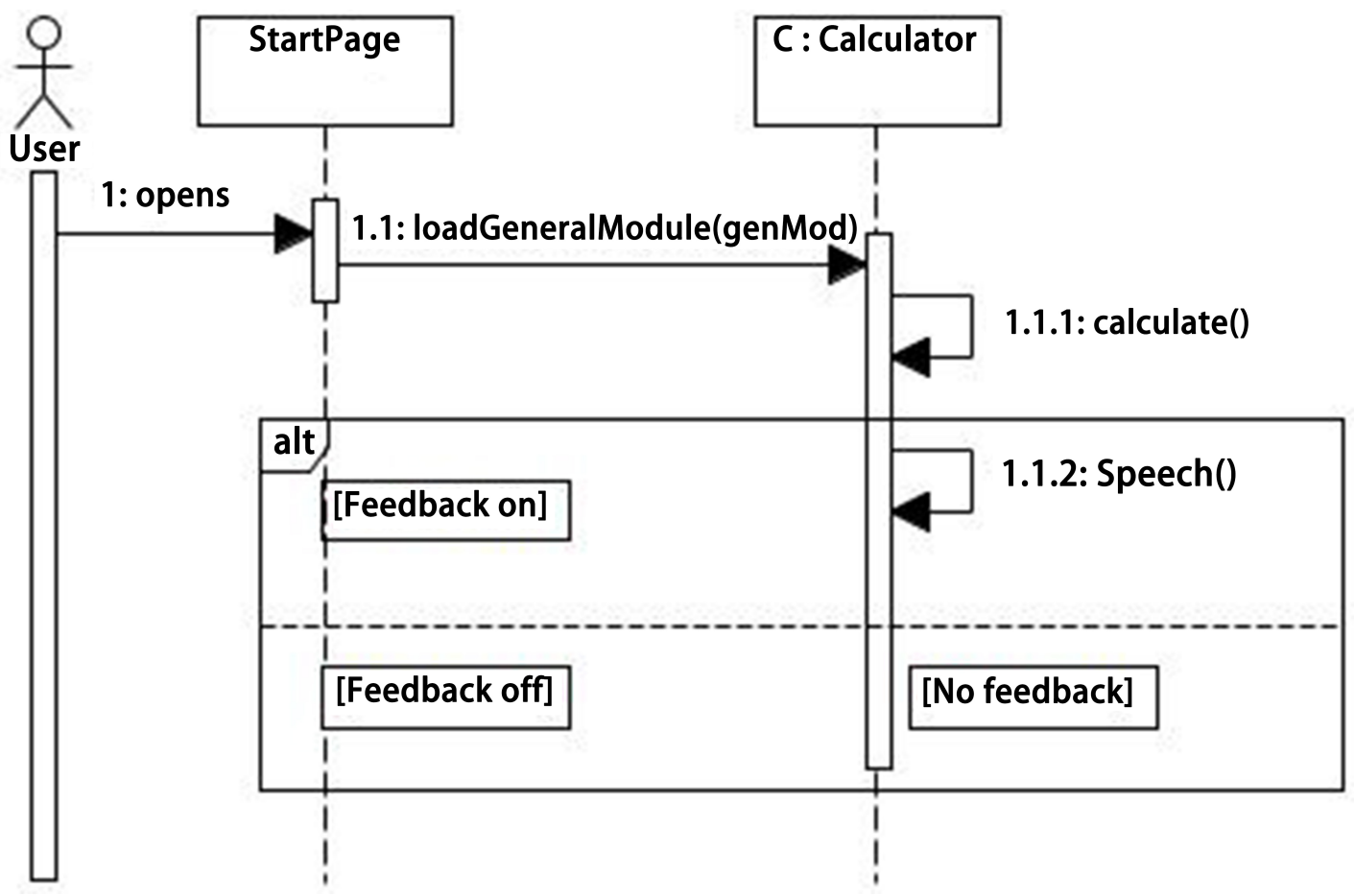

Figure 4. Sequence diagram for "access general module" activity

\section{Database Design}

This subsection considered the database design for the system. The XML (e-Xtensible Markup Language) was used for the system.

(3) XML (e-Xtensible Markup Language)

Extensible Markup Language (XML) is a simple, very flexible text format derived from Standard Generalized
Markup Language (SGML) (ISO 8879) [22]. XML tags identify the data and are used to store and organize the data, rather than specifying how to display it like HTML tags, which are used to display the data [23].

XML has many benefits that make it suitable for the Yorùbá number store of this project. They are:

a) XML is extensible which allows for the creation and use of custom self-descriptive tags or language that suits 
one's application.

b) XML allows us to store the data irrespective of how it will be presented.

c) Since XML are allowed to contain only Unicode characters, it is suitable for the storage of Yorùbá numbers which makes use of accented characters.

d) XML files are operating system and application independent which makes the system cross-compatible.

\section{(4) Application of XML Data Structure}

The XML data structure for this application specifies a root element called 'Yorùbá numerals'. This root element has sub-elements 'numeral' which captures the needed information about each number in the Yorùbá numeral system. Each 'numeral' sub-element has two child elements; the 'Arabic' child element holds the Arabic number and the 'yorùbá' child element will hold the Yorùbá number equivalent of that Arabic number. The XML data format is illustrated below:

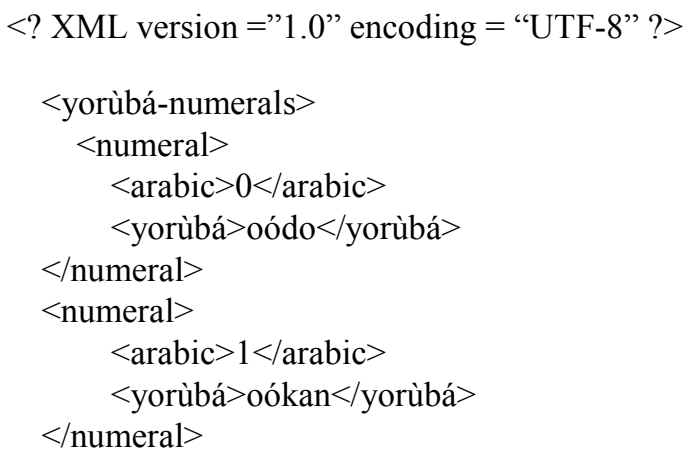

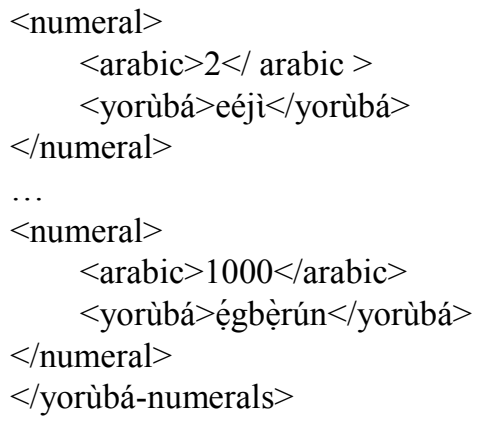

Python's dictionary data type is most suitable for this data structure as the XML's Arabic-Yorùbá element pair can easily be imported into the dictionary's key-value pair. The key will hold the Arabic number and the value will hold the corresponding Yorùbá equivalent.

\section{Software Implementation}

The front and back ends are discussed in this section. The front-end is meant for user interaction and the back-end is meant for the database and other internal features.

The identified actor of the Yorùbá arithmetic learning system is the user, who can perform a number of activities with each activity making up a use case. These use cases are combined to derive the use case diagram. The use case diagram for the Yorùbá arithmetic learning system is depicted in Figure 5.

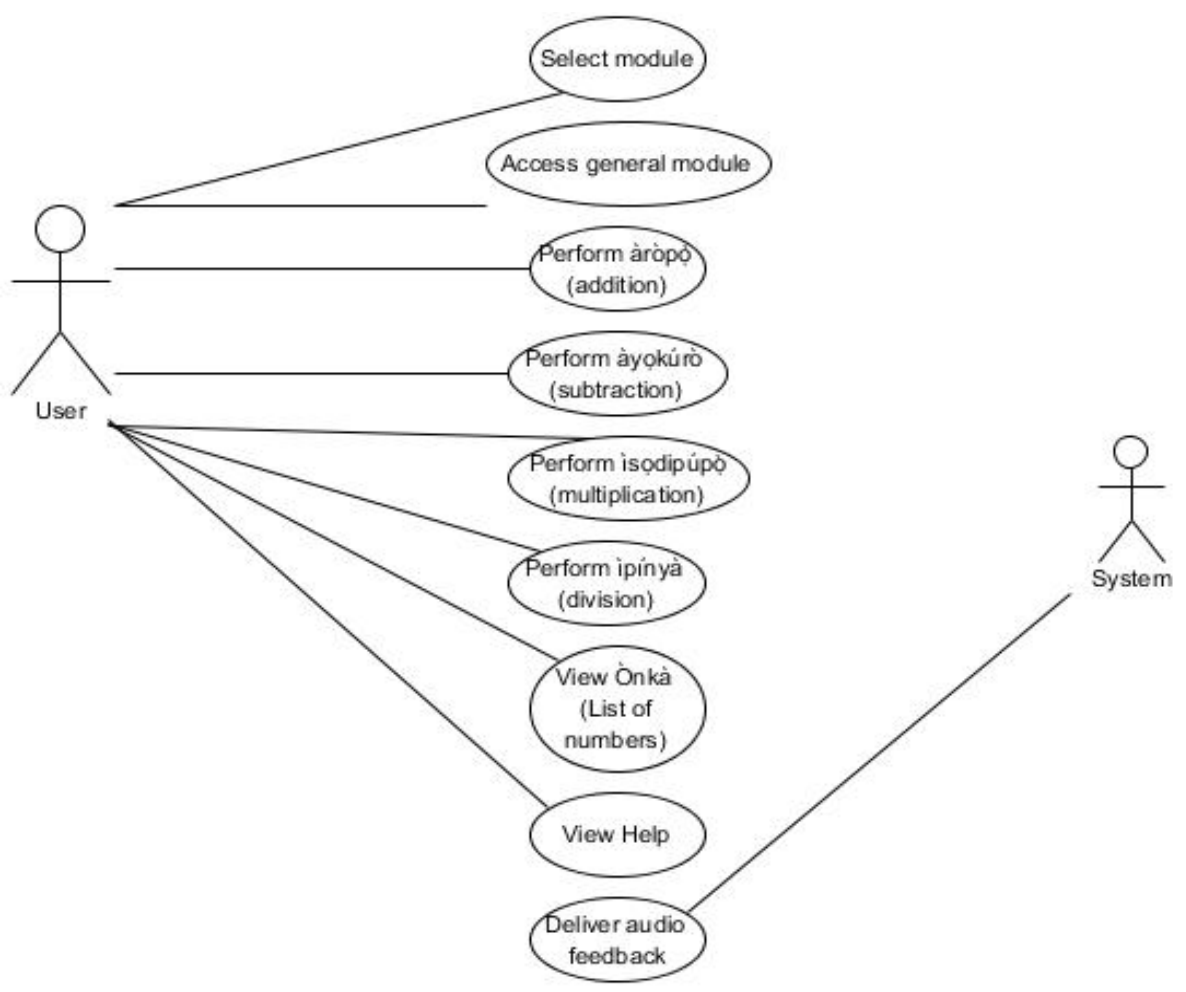

Figure 5. Use Case of the System 


\section{A. Front-End}

The first point of interaction with the software is the start page dialog which presents the user with a variety of choice, the calculator main window gives the user access to the Yorùbá calculator and the onka dialog gives the user access to view the list of numbers depending on the module selected either via the select module dialog interface or the module selected to access the calculator.

\section{(1) The Calculator Interface}

The calculator interface consists of several buttons through which the user can interact with the system. It can be seen from figure 6 that it has buttons corresponding to numbers 0 - 9 (oódo - ẹsán), 'pẹlu' button for addition, 'dín' button for subtraction, 'lọnà' button for multiplication and 'pín' for division. It also has 'CE' button to clear each entry in arithmetic expression and ' $\mathrm{C}$ ' button to clear the whole of the arithmetic expression altogether. The function of the 'switch' button is to switch between Yorùbá number view and Arabic number view. It can only perform this function after some arithmetic expression must have been evaluated, hence its disabled state at the start of the application. The 'Ònkà' button brings up the ònkà window where the user can view the list of number from 0 to the limit as specified by the module selected. Figure 7 shows the ònkà window. The 'Ìrànlọ́wộ' button brings up the help window showing the user how to make calculations with the software. The 'Padà' button brings up the start dialog in case the user wants to perform another action in the software not present on the calculator window.

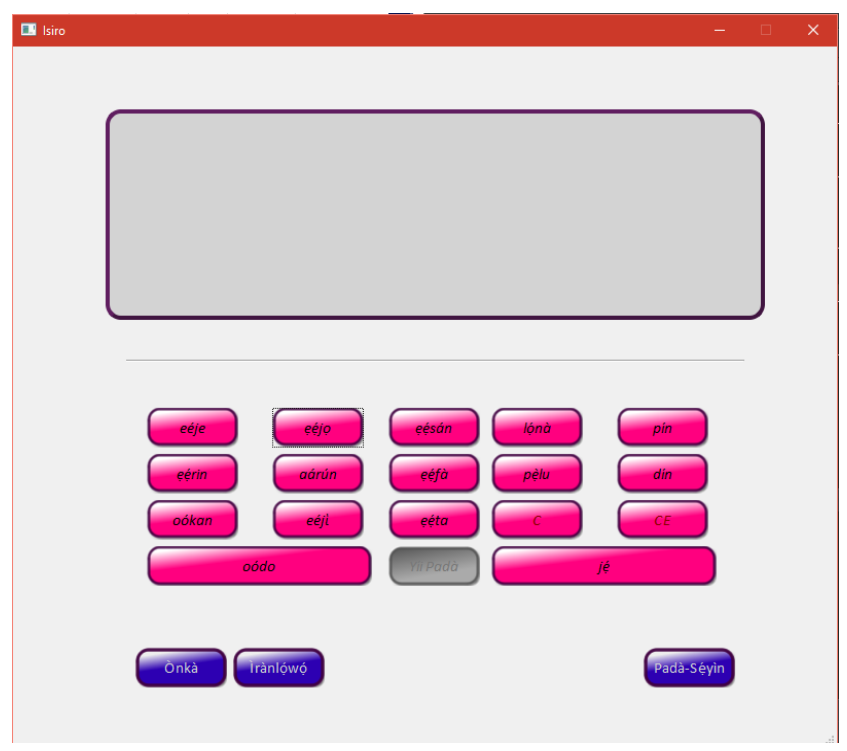

Figure 6. Calculator Main window Interface

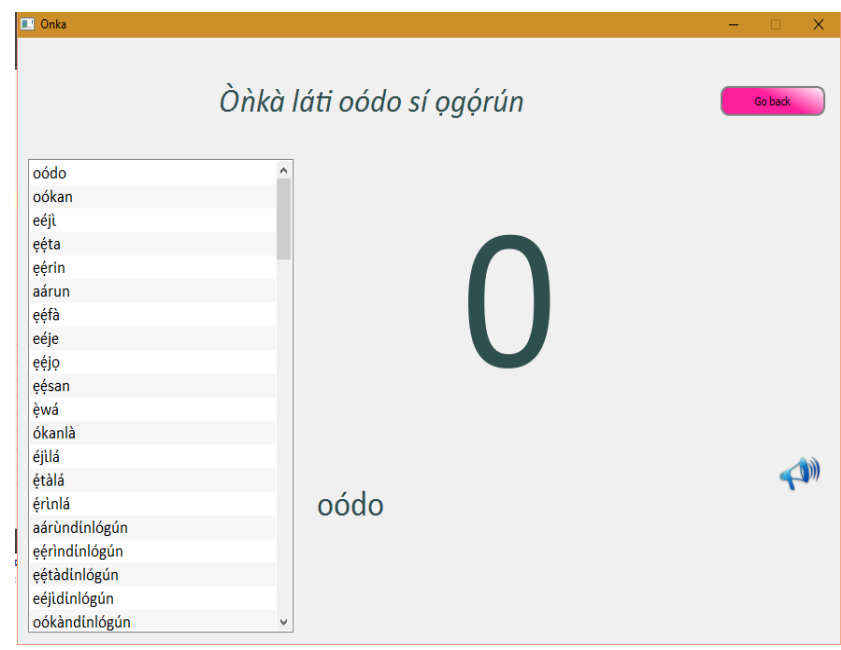

Figure 7. Ònkà window

\section{B. Back-End}

The back-end is the layer in which all arithmetic and logical operations occur. It is the backbone of the system as it drives the functionality of the system. It is also the layer where all program module and code resides.

\section{1) XML Parser Module}

The XML parser module is the module that reads the XML file holding the data structure for the Yorùbá numerals. It parses each numeral parent node and extracts the values of the Arabic and Yorùbá child nodes into a key-value pair which is stored in a python dictionary data structure. This dictionary is the one returned by this module into the main application which in turn manipulates the values inside the dictionary to achieve the desired effect. This module consists of a class 'xmlParser', the method importDom() which reads the XML file, the method populateFromDom() which parses the root element of the XML file and then makes use of the readNumeralMethod() method to populate the 'self._numbers' dictionary with our arabic-Yorùbá values. The method readNumeralNode() from 'xmlParser' class in the XML parser module is one that directly parses the numeral node.

\section{2) Sound Module}

The sound module is the one that provides the audio facilities for this software. It makes use of the QSound audio class of the pyqt GUI module. It consists of a class 'Speech' which has two methods - createSoundFile() and play(). The createSoundFile() method maps class argument 'num' to a corresponding pre-recorded sound file stored in the project directory. The play() method, in turn, plays this created sound file to give an audio effect to the software. 


\section{Calculator Module}

This is the module involved in the presentation of the main interface - the Yorùbá calculator and the user input processing. Thus, this module incorporates both the front-end and the back-end into one single file and class. This module consists of a class 'Calculator' which has various methods embedded in it to achieve various feature. The setModule () method is the one that sets the module to load according to the selection made by the user from the selectModule dialog or through the general module button on the start page dialog. The importXML() method imports the XML parser module into the calculator module. The on_btn_equal_clicked() method is the method executed whenever the 'jẹ' button is clicked. The calculate () method is the method that forms the Arabic and Yorùbá arithmetic expressions.

\section{3) Calculator Operations}

The four basic arithmetic operations can be done via the calculator interface - ìșirò (addition), àyọkúrò (subtraction), ìsodipúpọ̀ (multiplication) and pinpin (division).

a) Àròpọ̀ (Addition)

Addition can be done by pressing the button 'pẹ̀lu' between the two numbers to add. Figure 8 shows the calculator interface after the addition of two numbers.

\section{b) Àyọkúrò (Subtraction)}

Subtraction can be done by pressing the button 'dín' between the two numbers to subtract. Figure 9 shows the calculator interface after the subtraction of two numbers.

\section{c) İsodipúpọ̀ (Multiplication)}

Multiplication can be done by pressing button 'lọnà' between the two numbers to multiply. Figure 10 shows the calculator interface after the multiplication of two numbers.

\section{d) Pinpin (Division)}

Division can be done by pressing button 'pín' after the divisor and before the dividend. Figure 11 shows the calculator interface after the division of two numbers.

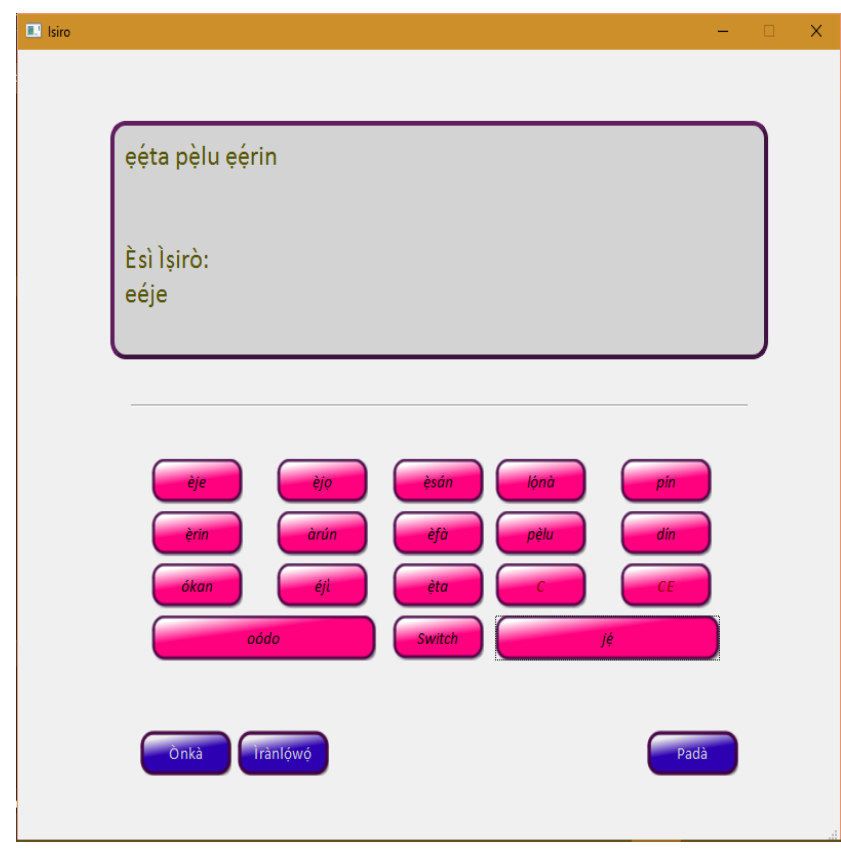

Figure 8. Addition of two numbers

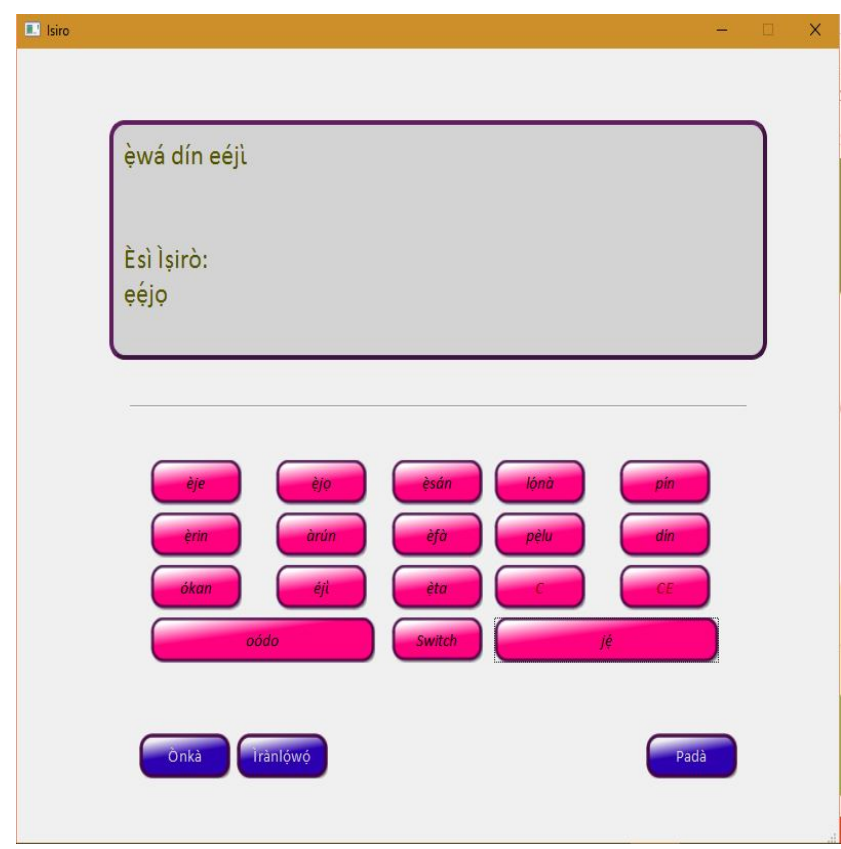

Figure 9. Subtraction of two numbers 


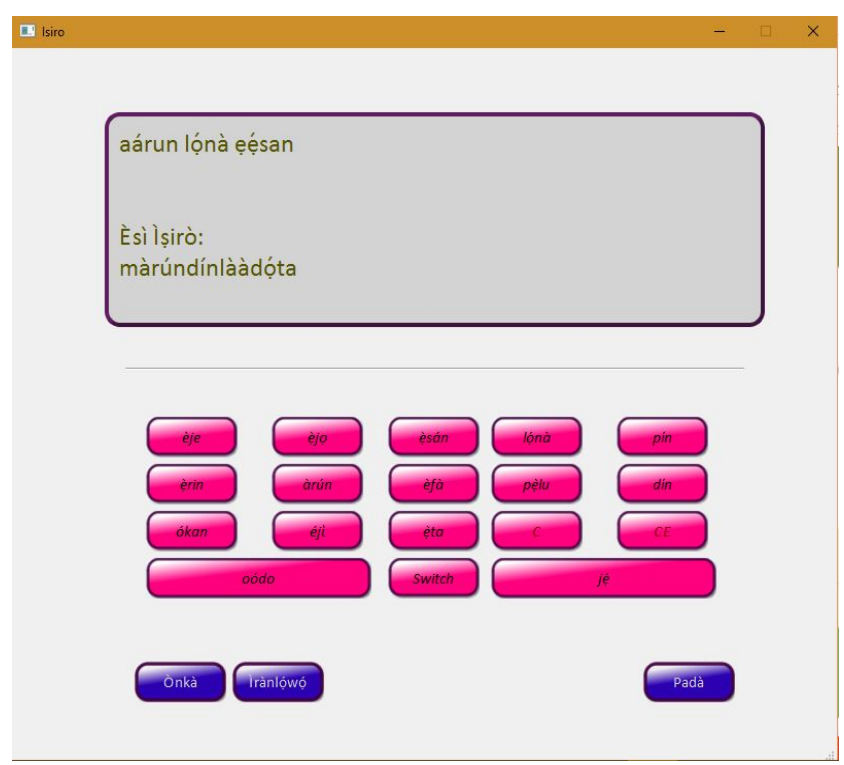

Figure 10. Multiplication of two numbers

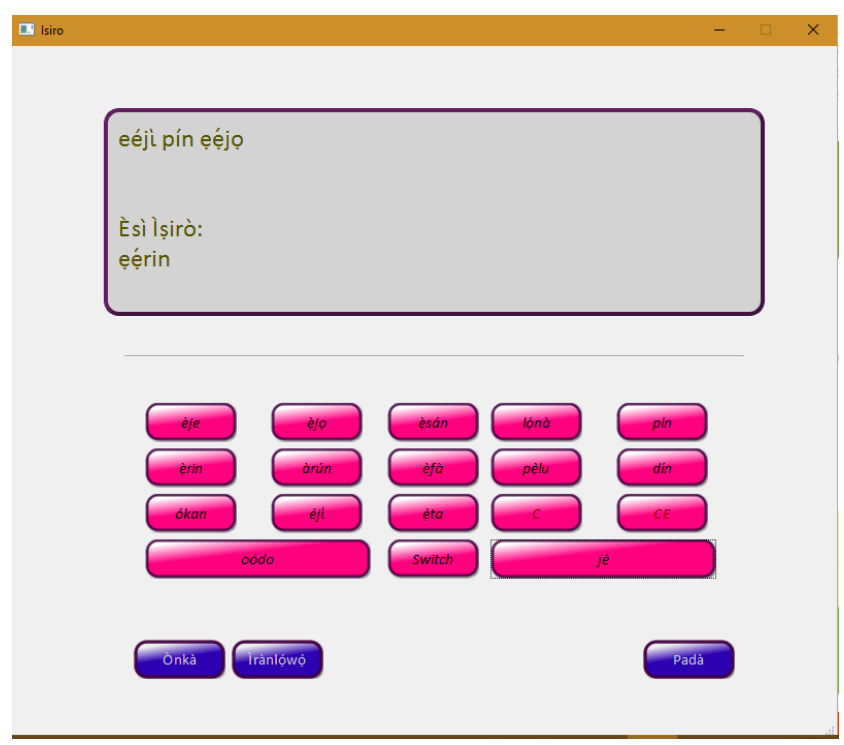

Figure 11. Division of two numbers

\section{Evaluation and Discussion}

The two testing approaches used are $\alpha$-Testing and $\beta$-testing. Yorùbá Arithmetic knowledge test was also done to determine how many of the users can truly perform arithmetic using the Yorùbá numeral system.

\section{A. Alpha-Testing}

This is the in-house testing. Each module in the system was unit tested and then incorporated into the system to observe if the module will behave the same way. The observations made during this stage were used to improve upon the system.

\section{B. Beta-testing}

This is the testing done by presenting the system to the intended users for evaluation. The test elicits user's information about the system's user interface, usability, and accuracy. The result was used to improve upon the design and dynamics of the system.

\section{1) Collection of Data}

Questionnaires were distributed to potential users requesting them to rate three test parameters - user interface, usability, and accuracy - on a scale of 1 to 5 where 1 is the lowest rating and 5 is the highest rating.

\section{2) Analysis and Interpretation of Data}

All data gathered from users were coded and analysed using Microsoft Excel, a spreadsheet processing software. The data is represented in table 1 which shows the rating of the test parameters above by each user and the average rating, and figure 12 is a bar chart of rating of the three test parameters.

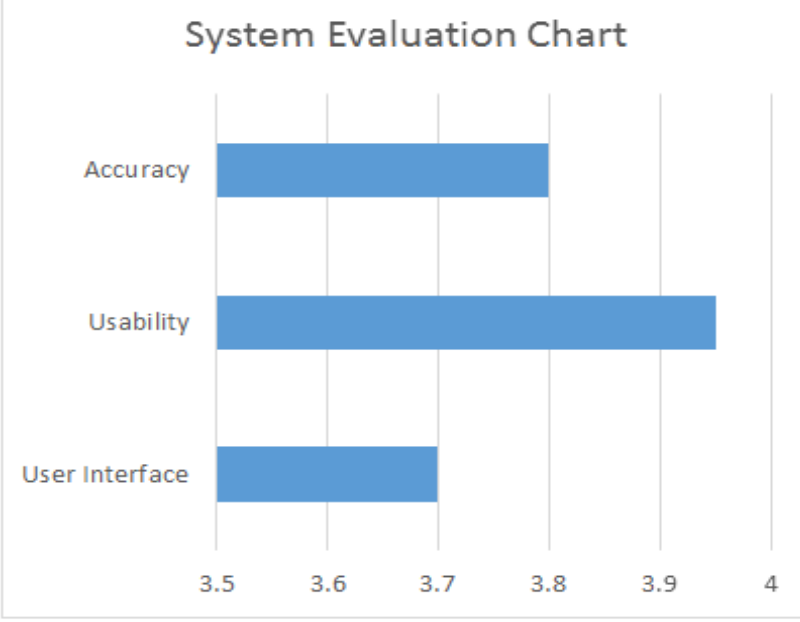

Figure 12. System Evaluation Bar Chart

Table 1. Beta-Test Data
\begin{tabular}{|c|c|c|c|}
\hline & User Interface & Usability & Accuracy \\
\hline 1 & 5 & 5 & 5 \\
\hline 2 & 4 & 4 & 3 \\
\hline 3 & 4 & 5 & 5 \\
\hline 4 & 4 & 4 & 5 \\
\hline 5 & 5 & 5 & 5 \\
\hline 6 & 4 & 4 & 4 \\
\hline 7 & 4 & 4 & 4 \\
\hline 8 & 4 & 4 & 3 \\
\hline 9 & 5 & 5 & 5 \\
\hline 10 & 4 & 3 & 4 \\
\hline 11 & 3 & 3 & 3 \\
\hline 12 & 2 & 3 & 2 \\
\hline 13 & 3 & 3 & 3 \\
\hline 14 & 3 & 3 & 3 \\
\hline 15 & 3 & 4 & 4 \\
\hline 16 & 3 & 3 & 4 \\
\hline 17 & 4 & 4 & 3 \\
\hline 18 & 3 & 3 & 4 \\
\hline 19 & 4 & 5 & 4 \\
\hline 20 & 3 & 5 & Sum $=76$ \\
\hline & Sum $=74$ & Sum $=79$ & 3.8 \\
\hline & Average $=3.7$ & Average $=3.95$ & Average $=3$ \\
\hline
\end{tabular}


Below is the interpretation of the analysis:

a) User Interface: Analysis shows that $95 \%$ of users find the user interface at the intermediate level and above but the remaining $5 \%$ think the user interface could still need modifications.

b) Usability: Analysis of the usability data revealed that all the users found the system adequately usable.

c) Accuracy: Analysis of the usability data revealed that $95 \%$ of the users found the system moderately accurate.

\section{3) Beta - Test Results' Discussion}

The average rating of each test parameter was determined from the data interpreted. The average rating for user interface was found to be 3.7, the average rating for usability was 3.95 and the average rating for accuracy was 3.8. Since the value of all test parameters is higher than the average, then the system can be said to meet user standards.

\section{A. Yorùbá Arithmetic Knowledge Test}

All data gathered from users were coded and analysed using Microsoft Excel, a spreadsheet processing software.

\section{1) Personal Information}

From the data gathered, $100 \%$ of the respondents had taken a Yorùbá language subject or course before but only $10 \%$ reported that the Yorùbá numeral system was not taught as part of the course. It was gathered that $10 \%$ of the respondents reported a very good Yorùbá numeral system knowledge level, $80 \%$ reported an average knowledge level while the remaining $10 \%$ reported a low-level knowledge.

In order to determine the how well users can perform Yorùbá arithmetic relative to the system developed, a section was included in the questionnaire to test their knowledge of Yorùbá arithmetic.

\section{2) 2) Data Collection}

Section A of the questionnaire asks the respondents if they have ever taken a Yorùbá language subject or course and if Yorùbá numeral system was ever taught as part of the subject or course while section $\mathrm{C}$ requests that the respondents evaluate sixteen (16) Yorùbá arithmetic expressions and give the answer back in Yorùbá using the accurate Yorùbá orthography.

\section{3) Analysis and Interpretation of Data}

This section discussed the results got from the data collected from the questionnaire. The results on the four arithmetic operations are discussed below.

\section{a) Addition Test Results}

Analysis of the results from the addition subsection revealed that $90 \%$ of the respondents were unable to evaluate any addition expressions, $5 \%$ were able to evaluate just one expression while the remaining $5 \%$ could perform two operations. Figure 13 is a pie chart depicting the data.

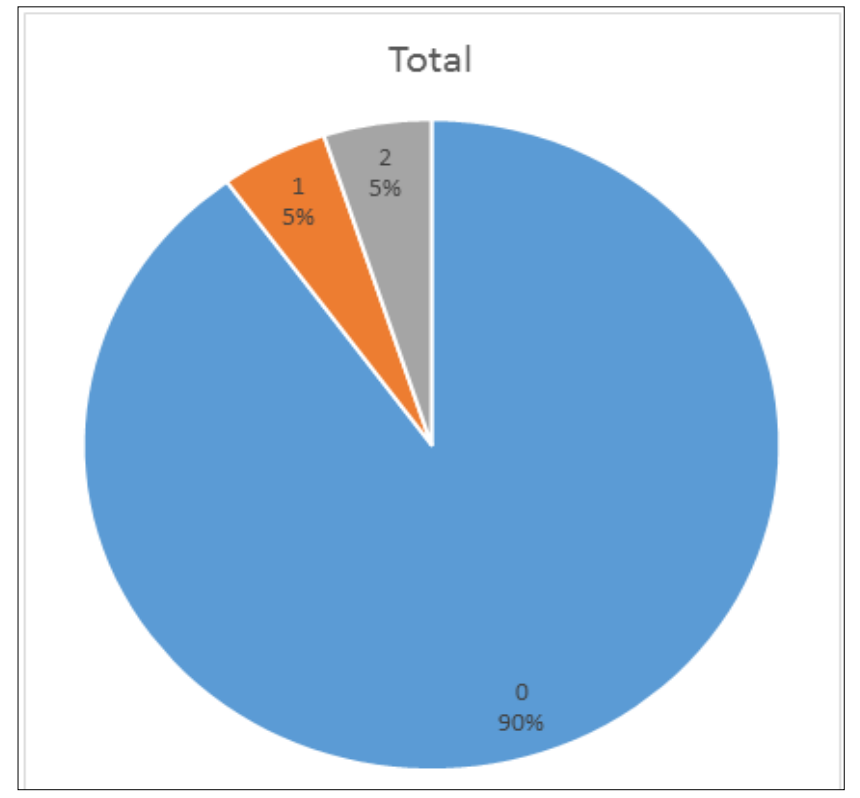

Figure 13. Addition Category Pie Chart

b) Subtraction Test Results

It was observed that $55 \%$ could not evaluate any subtraction expressions, $30 \%$ were able to evaluate just one expression, $10 \%$ were able to evaluate two expressions while $5 \%$ could evaluate three expressions out of the given. Figure 14 is a pie chart depicting the data.

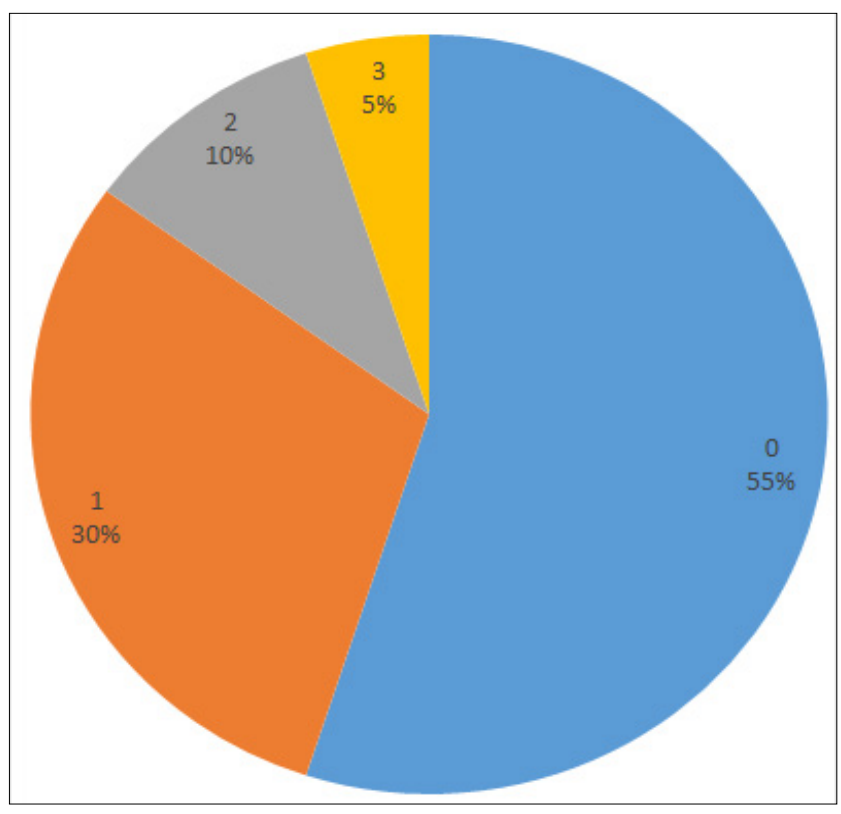

Figure 14. Subtraction Category Pie Chart

c) Multiplication Test Results

It was observed that $65 \%$ could not evaluate any multiplication expressions, $25 \%$ could evaluate just one expression, $5 \%$ were able to evaluate two expressions while the other $5 \%$ could evaluate three expressions. Figure 15 is a pie chart depicting the data. 


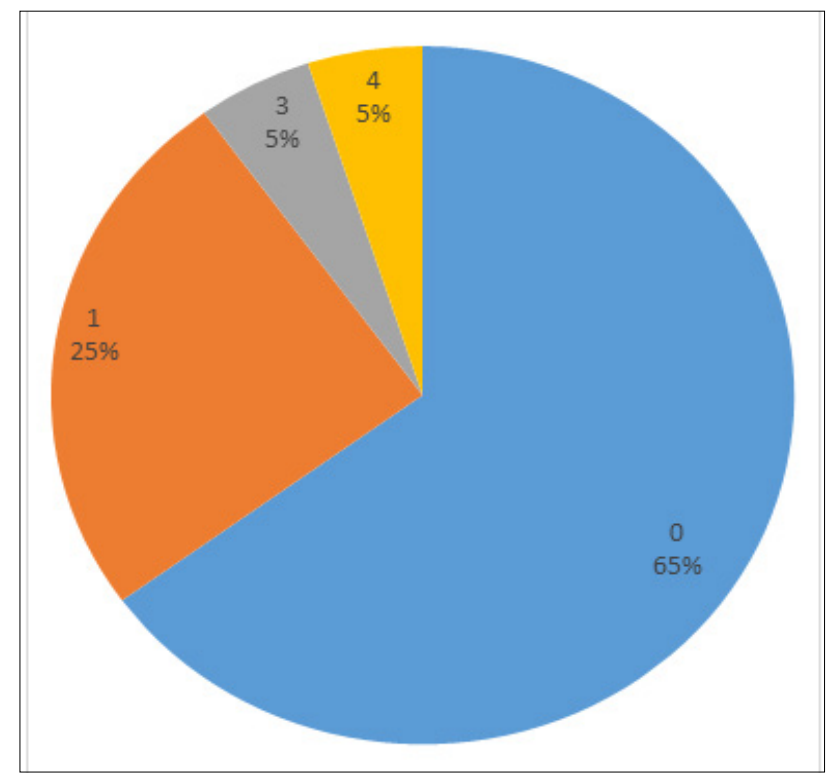

Figure 15. Multiplication Category Pie Chart

\section{d) Division Test Results}

It was observed that $90 \%$ of the respondents were unable to evaluate any division expressions while the other $10 \%$ could only evaluate just one expression. Figure 16 is a pie chart depicting the data.

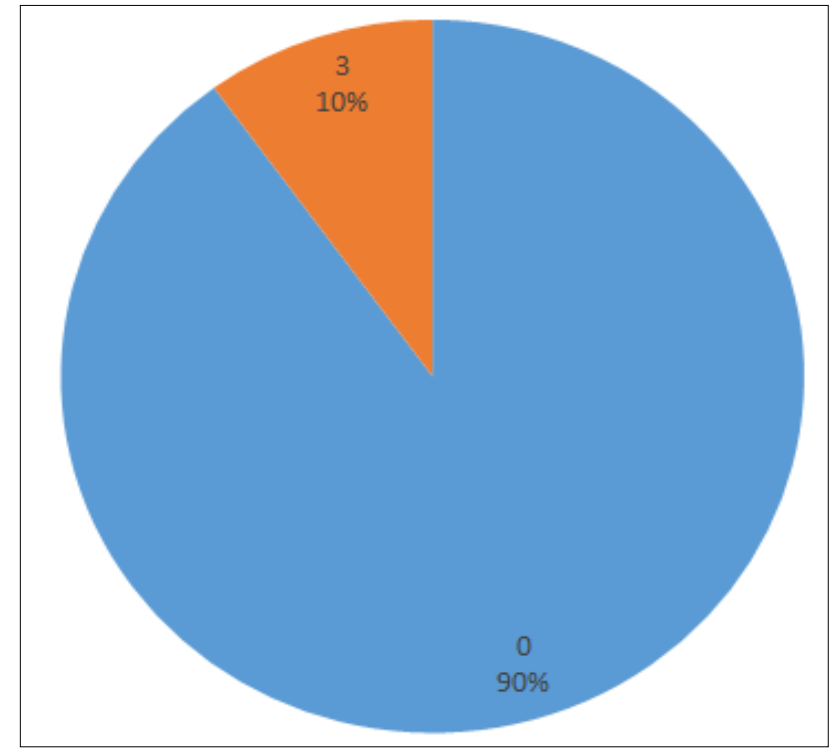

Figure 16. Division Category Pie Chart

4) Yorùbá Arithmetic knowledge test results' Discussion

It can be inferred from the data interpreted that at least $50 \%$ of users were unable to give correct answers to the arithmetic expressions. $10 \%$ of these users, however, were able to evaluate some expressions correctly but could not give the accurate Yorùbá orthographic representation of the answers. The other $50 \%$ included users which could only evaluate certain arithmetic expressions in each arithmetic operation category.
Thus, it can be concluded that the majority of the users of the system will be unable to perform arithmetic operations using Yorùbá numerals which give reason to the need for a system such as the one developed to help to familiarise and help people perform arithmetic operations in Yorùbá.

\section{Conclusions}

Following the successful completion of the project, it can be concluded from both research and system developed that in order to make the Yorùbá language more relevant in the world today, attempts such as this project must be encouraged. The issue of the almost non-existent use of Yorùbá numeral must be addressed by producing learning systems or aids to help the teaching and learning of the Yorùbá language numerals.

\section{REFERENCES}

[1] Bloomfield and Newmark (1963) Language. London: Allen and Unwin; New York; Holt, Rinehart and Winston Inc.

[2] Fabunmi F. A. and Salawu A. S. (2005) 'Is Yorùbá an endangered Language?'. Nordic Journal of African Studies 14(3): 391-408

[3] Woodbury, A. (2012) 'What is an Endangered Language?' Linguistic Society of America, Washington.

[4] Balogun T. A. (2013) 'An Endangered Nigerian Indigenous Language: The Case of Yorùbá Language'. African Nebula, Issue 6,70-82.

[5] Comrie, B. (2006). Endangered numeral systems. Paper presented at Max Planck Institute for Evolutionary Anthropology.

[6] Azeez A. S. (2013) 'The Yorùbá Language and Literature in the 21 st Century and Beyond' Covenant Journal of Language Studies (CJLS), Vol. 1, No. 2, 148-159.

[7] Babárìndé, O. (2013) 'The Linguistic Analysis of the Structure of the Yorùbá Numerals'. Journal of Literature, Languages, and Linguistics - An Open Access International Journal, Vol.1, 78-88.

[8] Oyèbádé, F. (2010), The Imperatives of Documenting Counting Systems in African Languages: A Window into the cognitive Process of Computation. Presented at the 2nd University of Uyo Conference on African Languages held September 19-24, 2010.

[9] Lounge, O. (2009). A vigesimal number system. Book builders.

[10] Òdúyoyè, M. (1969). Yorùbá: Numeration system. Ibadan. Daystar Press.

[11] Esiri, E. (2011). Numeral system of Yorùbá: Focus on the dialect of Oyo. An unpublished B.A. Dissertation.

[12] Adenegan, K. E., Raji S. M. and Adenegan, T. S (2014). The use of Yorùbá Indigenous Language in the Teaching and 
Learning of Mathematics in Nigerian Schools. International Journal of Science and Science Education, Vol. 5(1), pp. 53 59, December 2014. Available online at http://www.josseo.org $(12 / 02 / 2016)$

[13] Mbah B. M. (2012). 'Language Policy, Mother tongue Education and the Role of the Nigerian Language Teacher in Nigerian Language Education'. Journal of Education and Practice Vol 3, No 10, 48-54.

[14] Fakinlede K. J. (2006) Yorùbá Language in Science and Technology.

$<$ https://groups.google.com/d/topic/Yorùbáaffairs/_NcB9QO L5n $4>$

[15] Warschauer, M., Shetzer, H., and Meloni, C. (2000). The Internet for English teaching Washington, DC: TESOL.

[16] Beatty, K. (2003). Teaching and researching computer-assisted language learning. Great Britain: Pearson Education Limited.

[17] Vládia M. C. (2014). 'Are Esl/Efl Software Programs Effective for Language Learning?', Ilha Desterro no.66 Florianópolis Jan./June 2014, URL: http://dx.doi.org/10.500 7/2175-8026.2014n66p 19

[18] McKendrick, J. H., and Bowden, A. (1999). Something for everyone? An evaluation of the use of audio-visual resources in geographical learning in the UK. Journal of Geography in Higher Education 23(1), 9-20. Retrieved June 18, 2001, from Academic Search Elite on GALILEO:

http://www.galileo.peachnet.edu.

[19] Smith, B. K., and Blankinship, E. (2000). Justifying imagery: multimedia support for learning through exploration. IBM Systems Journal, 39(3/4), 749-768. Retrieved June 20, 2001, from Academic Search Elite on GALILEO: $<$ http://www.galileo.peachnet.edu $>$.

[20] Bryant, S. M. and Hunton, J. E. (2000). The use of technology in the delivery of instruction: implications for accounting educators and education researchers. Issues in Accounting Education, 15(1), 129-163. Retrieved June 18, 2001, from Academic Search Elite on GALILEO: http://www.galileo.peachnet.edu.

[21] Liam (2013-2015), 'Extensible Markup Language (XML)'. World Wide Web Consortium (W3C). Retrieved from http://www.w3.org/XML/. Last modified on 2015/05/19.

[22] Tutorials Point (2014). XML Tutorial, Tutorials Point (I) Pvt. Ltd. <www.tutorialspoint.com>

[23] Williamson, $\mathrm{K}$ and Blench R. 2000. "Niger-Congo Languagesee. D, Nurse Ed. African Languages: An Introduction. Cambridge: Cambridge University Press. 